Jurnal Widya Laksana, Vol.11, No.1, Januari 2022

\title{
PELATIHAN ENGLISH FOR BUSINESS DAN KEARSIPAN BAGI LULUSAN SMA/K ANAK BINA YAYASAN BULIR PADI
}

\author{
Syarief Darmoyo', Rakhdiny Sustaningrum ${ }^{2}$ \\ ${ }^{1,2}$ Fakultas Ekonomi dan Bisnis, Universitas Katolik Indonesia Atma Jaya \\ e-mail: syarief.darmoyo1@atmajaya.ac.id,rakhdiny.s@atmajaya.ac.id
}

\begin{abstract}
Abstrak
Dalam rangka mensukseskan Program Vokasi Pemerintah Bagi Lulusan Sekolah Menengah Atas (SMA) dan Sekolah Menengah Kejuruan (SMK), Fakultas Ekonomi dan Bisnis Universitas Katolik Indonesia Atma Jaya (FEB Unika Atma Jaya) dan Yayasan Bulir Padi berinisiatif untuk menyelenggarakan pelatihan vokasi bagi lulusan $S M A / K$. Tujuan pelatihan ini adalah meningkatkan skill anak bina Yayasan Bulir Padi yang sudah lulus SMA/K dalam melakukan percakapan Bahasa Inggris dan menangani masalahmasalah kearsipan di lingkungan perkantoran. Peserta pelatihan berjumlah sembilan orang dan dilaksanakan di FEB Unika Atma Jaya pada 26 dan 27 Juni 2019. Pelatihan difasilitasi oleh dosen-dosen FEB Unika Atma Jaya dengan menggunakan metode diskusi, bermain peran, menonton film, dan praktek. Pengukuran kualitatif terhadap hasil belajar peserta menunjukkan bahwa pengetahuan dan keterampilan berbahasa Inggris sederhana dan kearsipan mereka mengalami peningkatan setelah mengikuti pelatihan.
\end{abstract}

Kata kunci: bahasa inggris, kearsipan, pelatihan vokasi

\begin{abstract}
To make the Government Vocational Program for High School (SMA) and Vocational High School (SMK) Graduates successful, the Faculty of Economics and Business Atma Jaya Catholic University of Indonesia (FEB ACUI) and the Bulir Padi Foundation took the initiative to organize vocational training for SMA and SMK graduates. The purpose of this training is to improve the skills of Bulir Padi Foundation children who have graduated from SMA and SMK in teaching English and archiving issues in office environments. Training participants are nine people and held at FEB ACUI on 26 and 27 June 2019. FEB ACUI lecturers facilitated training using discussion methods, role-playing, watching movies, and practicing. The qualitative measurements of learning outcomes show that their knowledge and skills in simple English and their archives have increased after attending the training.
\end{abstract}

Keywords : english, archiving, vocational training 


\section{PENDAHULUAN}

Data Badan Pusat Statistik (BPS) menunjukkan bahwal per Agustus 2018 jumlah angkatan kerja di Indonesia ada sebanyak 131,01 juta orang. Dari jumlah angkatan kerja tersebut, 5,34\% (7 juta) di antaranya penganggur, dan Tingkat pengangguran terbuka (TPT) ini didominasi oleh lulusan Sekolah Menengah Kejuruan (SMK) (11,24\%), disusul lulusan Sekolah Menengah Atas (SMA)(7,95\%). Peneliti INDEF (Institute for Development of Economics and Finance), Eko Listiyanto (Bisnis.com,14/03/2019) mengungkapkan bahwa setidaknya ada dua faktor yang menyebabkan tingginya jumlah penganggur lulusan SMA/K dan PT, yaitu:

- Para lulusan PT terlalu memilih pekerjaan yang hendak dijalani selepas dunia pendidikan.

- Kemampuan atau skill yang dimiliki lulusan SMA/K dan PT tidak sesuai dengan kebutuhan industri saat ini.

Terkait dengan rendahnya kualitas para lulusan di atas, Presiden RI, Joko Widodo, menekankan pentingnya pembangunan SDM Indonesia melalui jalur pendidikan vokasi. Dalam rapat terbatas di Istana Merdeka, Jakarta (Kompas.com., 16/5/2019) Bapak Presiden mengungkapkan, "Supaya bonus demografi yang puncaknya ada kurang lebih tahun 2030 bisa kita manfaatkan, dan kita bisa melakukan pembangunan sumber daya manusia secara besarbesaran. Kuncinya adalah langkah perbaikan, reformasi di pendidikan dan pelatihan vokasi yang dilakukan secara terpadu dan terintegrasi".

Sejalan dengan Bapak Presiden, Menteri Ketenagakerjaan (Menaker), M.
Hanif Dhakiri (Suara.com, 28/11/2018) menyatakan bahwa pelatihan vokasi merupakan solusi yang cepat untuk meningkatkan kualitas kompetensi lulusan SDM Indonesia. Untuk itu, pemerintah melalui Kementerian Ketenagakerjaan (Kemnaker) menggenjot pelatihan vokasi di Balai Latihan Kerja (BLK) dengan cara meningkatkan akses masyarakat ke BLK sehinga siapapun dapat mengikuti pelatihan di BLK. Selain itu, Kemnaker juga memperkuat mutu pelatihan vokasi, yakni dengan menerapkan program 3R (Reorientasi, Revitalisasi, dan Rebranding) BLK.

Untuk mendorong pelaksanaan vokasi pada 2019, pemerintah telah mengalokasikan anggaran sebesar $\mathrm{Rp}$ 25,9 triliun. Angka itu meningkat 10,2 persen dibandingkan pagu belanja pengembangan vokasi pada 2018 yang sebesar Rp 23,5 triliun (Republika.co.id,8/11/2018).

Peningkatan anggaran ini mencerminkan bahwa pemerintah kita tidak main-main dalam mengatasi masalah angkatan kerja kita.

Undang - Undang Sistem Pendidikan Nasional Nomor 20 Tahun 2003 BAB IV menyebutkan bahwa setiap warga negara mempunyai hak yang sama untuk memperoleh pendidikan yang bermutu. Dengan demikian, setiap lulusan SMA/K memiliki hak yang sama untuk memperoleh pendidikan vokasi. Namun, hal ini rasanya sulit dipenuhi oleh pemerintah, mengingat jumlah lulusan SMA/K yang tidak sedikit dan tersebar di seluruh wilayah Indonesia. Karena itu, peran serta masyakat untuk membantu pemerintah mengatasi kesulitan tersebut sangat diharapkan, 
Jurnal Widya Laksana, Vol.11, No.1, Januari 2022

sebagaimana yang diamanahkan oleh Peraturan Pemerintah Republik Indonesia Nomor 39 Tahun 1992 Tentang Peranserta Masyarakat Dalam Pendidikan Nasional, yaitu : Masyarakat, baik itu perorangan, kelompok, atau organisasi nonpemerintah dapat ikut berperanserta dalam penyelenggaraan satuan pendidikan pada jalur pendidikan sekolah atau jalur pendidikan luar sekolah. Dalam kerangka inilah, Fakultas Ekonomi dan Bisnis (FEB) Unika Atma Jaya-Indonesia Jakarta bekerjasama dengan Yayasan Bulir Padi menyelenggarakan pelatihan vokasi kepada lulusan SMA/K yang merupakan anak bina Yayasan Bulir Padi.

Yayasan Bulir Padi adalah sebuah organisasi nirlaba yang berkomitmen untuk berkontribusi dalam pendidikan anak-anak kurang mampu di pinggiran Kota Jakarta. Di tahun 2019 ini, salah satu program kerjanya adalah mencetak anak-anak bina yang mempunyai keterampilan yang dapat menjawab kebutuhan industri melalui pemberian pelatihan kesiapan kerja dengan nama program Mandiri Berdikari dimana salah satu kegiatannya adalah pelatihan vokasi. Pelatihan vokasi ini dirancang bagianak bina secara gratis, agar anak bina mempunyai kesempatan yang sama untuk bertumbuh dan siap berkompetisi di dunia kerja dan pada akhirnya mampu hidup secara mandiri dan berkelanjutan. Tujuan pelatihan ini adalah memberikan dan menyiapkan anak bina Yayasan Bulir Padi yang sudah lulus SMA/K untuk masuk di dunia kerja, utamanya manajemen perkantoran, pembukuan akuntansi sederhana baik menggunakan excel maupun manual, dan Bahasa Inggris untuk Bisnis.

Menurut pengurus Yayasan Bulir Padi, anak bina mereka kurang memiliki pengetahuan dan keterampilan yang diperlukan untuk memasuki dunia kerja seperti : manajemen perkantoran (komunikasi dan kearsipan), pembukuan akuntansi sederhana baik menggunakan excel maupun manual, dan Bahasa Inggris untuk Bisnis. Oleh karena itu, mereka memandang perlu memberikan pelatihan agar anak bina mereka menguasai pengetahuan dan keterampilan tersebut sehingga siap memasuki dunia kerja.

Dalam program pelatihan vokasi kali ini, Yayasan Bulir Padi bekerja sama dengan Unika Atma Jaya sebagai bentuk sinergi antara lembaga swadaya masyarakat dengan civitas akademika dalam menyelesaikan masalah sosial, utamanya dibidang pendidikan, dan terbatas hanya pada pelatihan Bahasa Inggris dan Kearsipan. Secara khusus pelatihan vokasi ini bertujuan untuk:

- Memberikan pemahaman dan keterampilan tentang kosakata, pelafalan, teknik dan etika dalam percakapan Bahasa Inggris Bisnis.

- memberikan pemahaman dan keterampilan tentang pengertian, pentingnya, dan prosedur penanganan arsip perkantoran.

\section{METODE}

Sasaran pelatihan ini adalah para lulusan sekolah lanjutan tingkat atas yang merupakan anak bina Yayasan Bulir Padi yang berjumlah sembilan orang. Mereka ada yang lulusan SMK dan ada juga lulusan SMA. Semua lulusan SMK/A tersebut sebelumnya 
belum pernah mengikuti pelatihan tentang Bahasa Inggris untuk Bisnis dan Kearsipan. Pelatihan ini dilaksanakan di Unika Atma Jaya pada Kamis, 26 dan Jumat, 27 Juni 2019 dari pukul 09.30 sampai 15.30 .

Model pembelajaran yang diterapkan dalam pelatihan ini adalah Student-Centered Learning (SCL). Menurut Ang (2001), SCL adalah model pembelajaran yang memfasilitasi peserta didik untuk berpartisipasi aktif dalam proses pembelajaran. Model pembelajaran ini dipilih karena memiliki beberapa keunggulan seperti memandang peserta didik sebagai pusat pembelajaran, memacu semangat peserta didik untuk terus belajar, membuat peserta didik lebih mandiri dalam proses pembelajaran, dan memungkinkan peserta didik belajar dari berbagai sumber belajar yang ada (Attard, 2010). Ada pun metode pembelajaran yang digunakan yaitu : ceramah, diskusi, bermain peran, menonton film, dan praktek.

Prosedur pelaksanaan kegiatan pelatihan ini dilakukan dengan langkahlangkah sebagai berikut:

- Mengidentifikasi kebutuhan pelatihan. Sebagaimana yang telah dikemukan pada bagian sebelumnya, pada 2019 ini Yayasan Bulir Padi mengembangkan program vocational training untuk anak bina mereka. Untuk merealisasikan program ini, Yayasan Bulir akan bekerjasama dengan berbagai lembaga yang memiliki kompetensi di bidang pendidikan vokasi. Salah satunya adalah FEB Unika Atma Jaya. Dari diskusi dengan pengurus Yayasan Bulir Padi, beberapa kebutuhan pelatihan dapat diidentifikasi yaitu manajemen perkantoran (komunikasi dan kearsipan), pembukuan akuntansi sederhana baik menggunakan excel maupun manual, dan Bahasa Inggris untuk Bisnis. Namun, pada pelatihan kali ini hanya terbatas pada kebutuhan Bahasa Inggris untuk Bisnis dan Kearsipan.

- Setelah bersepakat mengadakan pelatihan Bahasa Inggris untuk Bisnis dan Kearsipan, selanjutnya FEB Unika Atma Jaya dan Yayasan Bulir Padi berbagi peran, yaitu :Yayasan Bulir Padi bertanggung jawab atas kehadiran anak bina sebagai penerima manfa'at program, sedangkan Unika Atma Jaya bertanggung jawab atas kesiapan materi, pengajar dan fasilitas pembelajaran lainnya.

- Selanjutnya, FEB Unika Atma Jaya membentuk tim pengabdian masyarakat, membuat desain pelatihan, menentukan tanggal dan tempat pelatihan, mengurus perijinan, booking ruangan, membuat hand out, dan memilih media pembelajaran.

- Berikutnya melaksanakan pelatihan, yang diawali dengan acara pembukaan oleh Ketua Prodi Manajemen FEB Unika Atma Jaya dan Pengurus Yayasan Bulir Padi. Kemudian, dilanjutkan dengan penyajian materi oleh fasilitator Bahasa Inggris untuk Bisnis dan Kearsipan.

- Terakhir, melakukan evaluasi terhadap efektivitas pelatihan untuk mengetahui sejauh mana pelatihan telah mencapai tujuan yang diharapkan. Dalam hal ini, evaluasi dilakukan dengan metode 
pengukuran kualitatif. Untuk melengkapi data efektivitas pelatihan, pelatihan ini melakukan evaluasi terhadap kualitas pelatihan untuk mengetahui persepsi peserta mengenai efektifitas materi, efektifitas fasilitator, kualitas penyelenggaraan, dan kualitas fasilitas pelatihan. Selain itu, pelatihan ini juga melakukan observasi terhadap antusiasme dan keaktifan peserta dalam kegiatan pembelajaran, serta wawancara dengan peserta untuk mengetahui sejauh mana manfaat pelatihan bagi mereka dan apa saja yang perlu diperbaiki dari pelatihan saat ini agar pelatihan berikutnya jauh lebih baik.

Pelatihan ini memanfaatkan film sebagai media pembelajaran yang diunduh dari : 1 ) https://www.youtube.com/watch? $v=\mathrm{mPI}$ s9fEAowQ dan https://www.youtube.com/watch?v=wyq fYJX23lg. Film pertama berisi pengertian, pentingnya, dan prosedur penanganan arsip. Film kedua berisi tentang bagaimana cara resepsionis menyambut tamu hotel dengan cara yang sopan. Selain itu, pelatihan ini juga memanfaatkan media microsoft power point, in focus, dan laptop/komputer, serta membuat hand out untuk membantu peserta mendalami materi yang disampaikan oleh fasilitator. Untuk memperoleh data evaluasi kualitas pelatihan, pelatihan ini mengembangkan kuesioner sebagai instrumen pengumpulan datanya. Kuesioner tersebut berisi pertanyaanpertanyaan tentang materi, fasilitator, penyelenggaraan, dan fasilitas pelatihan dengan pilihan jawaban dari sangat kurang (1) sampai sangat baik (5).

\section{HASIL DAN PEMBAHASAN}

Pelatihan sesi pertama dilaksanakan pada Kamis, 26 Juni 2019 Jam 13.00 - 15.00. Materi pelatihan sesi pertama adalah English for Business. Acara pelatihan diawali dengan kata sambutan yang disampaikan oleh Ketua Prodi Manajemen FEB Unika Atma Jaya dan juga Yayasan Bulir Padi..

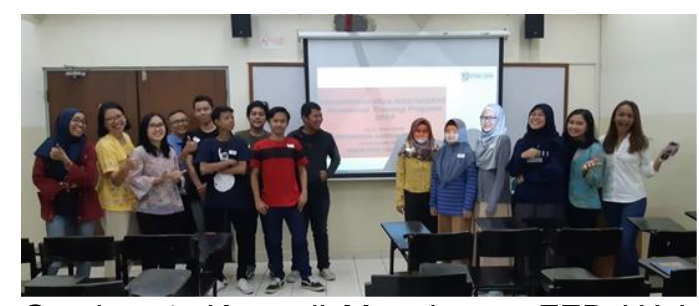

Gambar 1. Kaprodi Manajemen FEB UAJ, Perwakilan Yayasan Bulir Padi, Tim fasilitator, dan Peserta berfoto bersama usai acara pembukaan

Berikutnya, acara dilanjutkan dengan penyajian materi oleh fasilitator. Ada pun poin-poin penting yang disampaikan oleh fasilitator adalah:

- Bagaimana cara menelepon yang sopan dengan konsumen, yaitu: jawab telepon sebelum deringan ketiga, gunakan bahasa yang sopan (misalnya, apakah kamu mau...?), gunakan nama pelanggan selama percakapan, tunjukkan keseriusan permintaan pelanggan, katakan terima kasih.

- Tata cara penyambutan telpon dengan pengenalan diri, menyampaikan maksud dan tujuan dalam menelpon, meninggalkan pesan, dan menawarkan bantuan. 
- Tata cara etika untuk menyambut, melayani, dan mengantarkan tamu perusahaan ke departemen yang dituju

- Tata cara untuk menyambut telepon dengan menggunakan bahasa Inggris

- Tata cara untuk menjawab email dengan menggunakan bahasa Inggris

- Pemahaman dan pelatihan dalam menggunakan intonasi suara sebagai front liner

- Tata cara berbusana dan bahasa tubuh yang baik dan profesional dalam perusahaan

- Tata cara penyambutan telpon dengan pengenalan diri, menyampaikan maksud dan tujuan dalam menelpon, meninggalkan pesan, dan menawarkan bantuan.

Materi-materi tersebut disajikan oleh fasilitator dengan menggunakan metode ceramah, tanya-jawa dan diskusi. Sesi pertama pelatihan diakhiri dengan menonton nonton video tentang bagaimana cara resepsionis menyambut konsumen dengan cara yang sopan.

Materi menyambut konsumen atau menerima telepon merupakan salah satu langkah awal yang diberikan dalam pengenalan karyawan yang bekerja di perusahaan. Hal ini merujuk pada buku English for Business terbitan Cambridge dan Oxford bahwa menyambut konsumen dan menerima telepon adalah salah satu dasar dari kesopanan dan etika karyawan yang setelahnya diikuti dengan kemampuan dalam bernegosiasi, melakukan presentasi, dan pengenalan budaya perusahaan. Namun, pada kegiatan pengabdian ini, kebutuhan siswa yang akan melanjutkan untuk bekerja ditargetkan dapat memiliki bekal untuk memiliki etika yang baik sebagai salah satu kemampuan lebih.

Dalam sesi ini, siswa diajarkan pula bagaimana pelafalan dan sistematika penulisan secara grammatical. Fasilitator tidak menemui kesulitan dalam mengajarkan bagaimana menggunakan bahasa Inggris sebagai pengantar karena pada umumnya siswa sudah mendapatkan bekal bahasa dan struktur ketika di sekolah menengah dan pada sesi ini hanya menegaskan bagaimana waktu dan pemakaian yang tepat untuk penggunaan bahasa Inggris secara formal dan informal sehingga siswa dapat memahami perbedaannya.

Sesi ini memberikan pembekalan berupa materi handout, latihan untuk dapat dikerjakan di rumah dan dibaca kembali sebagai panduan di rumah. Role play dalam sesi ini mendorong pula siswa untuk lebih memahami secara praktik. Keluaran/output dalam sesi ini diharapkan siswa memahami tata cara dan etika sebagai front liner dalam perusahaan dan memberikan ke-

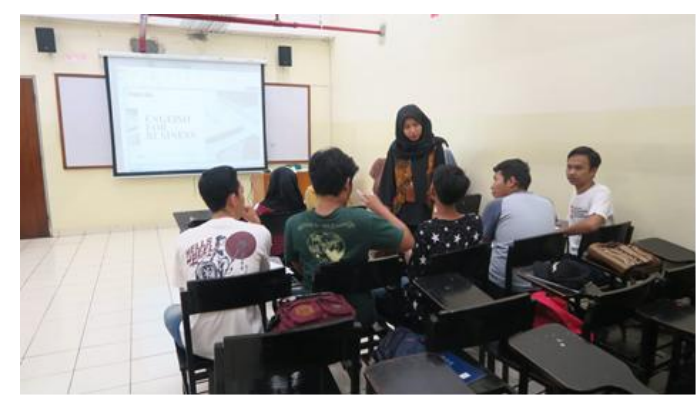

Gambar 2. Fasilitator dan peserta sedang berdiskusi tentang cara bertelepon dengan konsumen 


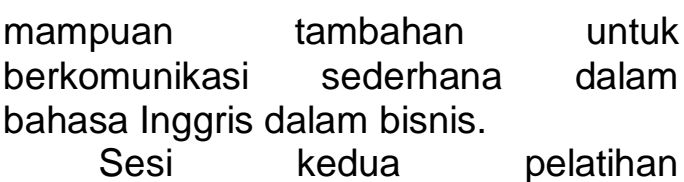
dilaksanakan pada Jumat, 27 Juni 2019 dari 9.30 - 12.00. Materi pelatihan sesi dua adalah tentang arsip dan kearsipan. Dalam awal penjelasannya, fasilitator mengajak peserta untuk berdiskusi tentang bagaimana cara menangani surat yang masuk dan keluar perusahaan. Setelah mereka memahami masalah-masalah yang muncul jika tidak ditangani dengan baik dan bagaimana solusinya, kemudian fasilitor menjelaskan arsip dan kearsipan. Penjelasan fasilitator ini diawali dengan menonton video tentang arsip dan kearsipan. Selanjutnya, fasilitator mengajak peserta bermainperan tentang penanganan surat masuk dan keluar. Dalam bermainperan ini ada 5 pemeran yang harus dimainkan peserta, yaitu : Kepala Sekolah, Sekretaris Kepala Sekolah, Petugas Surat, Agendaris, dan Penerima dan Pengirim Surat. Untuk itu, peserta dibagi ke dalam kelima jenis pemeran tersebut. Sebelum bermainperan dimulai, fasilitator menjelaskan sekenarionya dan setiap pemeran diminta untuk mempelajari tugasnya masing-masing. Setelah selesai bermainperan, fasilitator melakukan debriefing tentang pelajaran apa yang dapat dipetik dari bermainperan tersebut. Pelatihan sesi kedua diakhiri dengan praktek indexing dan cara menemukan kembali arsip yang disimpan.

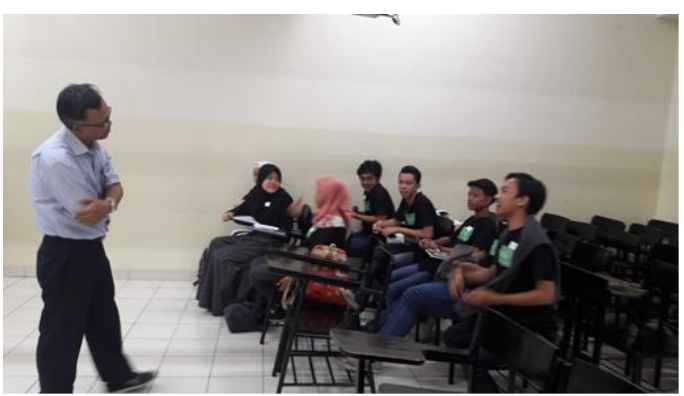

Gambar 3. Fasilitator dan peserta sedang berdiskusi mengenai penanganan surat masuk dan keluar

Sebagaimana yang telah disebutkan di muka, pelatihan ini mengaplikasikan metode pengukuran kualitatif untuk menentukan efektivitas pelatihan. Dalam hal ini, sebelum pelatihan peserta dites terlebih dahulu untuk mengetahui sejuh mana mereka menguasai materi-materi yang akan disampaikan oleh fasilitator (pre-test), kemudian setelah pelatihan mereka dites kembali untuk mengetahui sejauh mana mereka telah menguasai materimateri yang disampaikan oleh fasilitator (post-test). Pengumpulan data pre-test dan post-test ini dilakukan dengan cara bertanya-jawab dengan peserta (teknik wawancara). Perbandingan pre-test dan post-test menunjukkan bahwa ada perubahan pengetahuan dan keterampilan peserta dalam hal melakukan percakapan bahasa Inggris sederhana, dan juga kearsipan seperti:

- Percakapan bahasa Inggris "Jangan pakai Will you ketika menawarkan sesuatu pada tamu tapi pakai kata Would you, itu jauh lebih sopan." (peserta 2)

"Gunakan kalimat 'I'm looking forward hearing feedback from you soon', klo ingin membalas email pakai bahasa inggris." (peserta 9) 
"Kalo sedang menjamu tamu perusahaan, katakan, 'Please let me know if you need further assistance'..." (peserta 5)

- Kearsipan

"Contoh arsip misalnya surat pengangkatan pegawai, notulen rapat pimpinan dan stafnya, laporan pertanggungjawaban, film tentang perusahaan, dsb." (peserta 1)

"Menurut saya, fungsi arsip yaitu sebagai sumber informasi...jadi, arsip berisi informasi-informasi tentang aktivitas-aktivitas perusahaan." (peserta 8)

“...arsip sebagai bahan pertanggungjawaban....misalnya, organisasi melaksanakan kegiatan Maulid Nabi... laporan kegiatannya... itulah berfungsi sebagai bahan pertanggungjawabannya..." (peserta 3) meningkatkan pengetahuan dan keterampilan mereka mengenai Bahasa Inggris untuk Bisnis dan kearsipan, dan materi yang disampaikan oleh fasilitator sudah cukup jelas. Selain materi, fasilitator juga memperoleh penilaian yang baik dari peserta. Dengan demikian, fasilitator dipandang peserta menguasai dan terampil dalam menyampaikan materi, mendorong peserta untuk terlibat aktif dalam proses pembelajaran, efektif dalam menggunakan media dan metode pembelajaran, mampu membangun komunikasi yang baik antara fasilitator dengan peserta, dan dapat mengelola waktu pembelajaran dengan baik. Sama seperti fasilitator, penyelenggara pelatihan juga memperoleh penilaian yang baik dari peserta. Hal ini berarti peserta melihat durasi waktu pelatihan sudah cukup dan mahasiswa sebagai asisten pelatihan memiliki sikap yang baik terhadap mereka selama kegiatan pelatihan berlangsung. Berbeda dengan materi, fasilitator, dan penyelenggara pelatihan, fasilitas

Tabel 1. Kualitas Pelatihan

\begin{tabular}{clcc}
\hline No. & Item yang diukur & Mean & Kesimpulan \\
\cline { 1 - 2 } 1 & Materi & 4,0 & Baik \\
\cline { 1 - 1 } 2 & Fasilitator & 4,0 & Baik \\
\cline { 1 - 1 } 3 & Penyelenggara pelatihan & 3,7 & Baik \\
\cline { 1 - 1 } 4 & Fasilitas pelatihan & 4,2 & Sangat Baik \\
\hline
\end{tabular}

Tabel 1 menyajikan hasil evaluasi terhadap kualitas pelatihan. Dari tabel tersebut, tampak materi memperoleh penilaian yang baik dari peserta. Hal ini berarti penyampaian materi yang dilakukan oleh fasilitator dianggap sudah efektif dan sesuai dengan tujuan yang diharapkan, pelatihan dapat pelatihan memperoleh penilaian yang sangat baik dari peserta. Jadi, menurut peserta ruang yang digunakan untuk pelatihan sangat layak dan nyaman, alat tulis yang disediakan panitia sangat lengkap, dan komputer dan sound system di ruang pelatihan dalam kondisi sangat prima. Dengan 
demikian, kualitas pelatihan ini dapat dikatakan baik.

Hasil observasi menunjukkan bahwa peserta tampak sangat antusias dan aktif dalam mengikuti kegiatan pembelajaran. Hal ini ditunjukkan dengan cara mereka mengajukan pertanyaan-pertanyaan terhadap materi yang disampaikan fasilitator, merespon permintaan fasilitator untuk menjawab pertanyaan peserta lain, dan memberikan opini terhadap isu-isu yang dilontarkan fasilitator. Selain itu, mereka mengerjakan tugas-tugas yang diberikan oleh fasilitator dan juga mengikuti setiap kegiatan yang diadakan oleh fasilitator seperti diskusi dan bermain peran.

Hasil wawancara menunjukan bahwa peserta mengaku bertambah pengetahuannya, terpacu ingin belajar lebih jauh dan ilmu yang mereka peroleh dapat mempersiapkan mereka untuk memasuki dunia kerja, sebagaimana yang mereka ungkapkan dalam wawanacara berikut:

"Pelatihan ini menambah wawasan saya yang tadinya kurang mengerti jadi lebih mengerti, misalnya, sebagai cerminan perusahaan intonasi suara dan etika front liner dalam menjawab telepon sangatlah penting, seperti dengan nada halus, tertata, dan jelas" (peserta 6)

"Pelatihan kali ini sangat memberikan ilmu yang bermanfaat apalagi materi yang diberikan diluar yang saya pelajari. Dan ini membuat saya terpacu untuk belajar lebih banyak hal lagi." (peserta 7)
"Pelatihan ini sangat bermanfaat untuk menambah ilmu, untuk kesiapan kerja dan lain-lain. Jadi, saya lebih percaya diri untuk melamar pekerjaan, karena saya tahu bagaimana memilih busana secara profesional dan bersikap selama bekerja." (peserta 4)

Karena itu, mereka menyarankan agar pelatihan serupa diadakan kembali dan waktunya perlu ditambah. Berikut saran-saran mereka:

"Semoga ada lagi pelatihan seperti ini untuk menambah wawasan." (peserta 8)

"Mungkin untuk waktu yang diberikan untuk pelatihan ini bisa ditambah." (peserta 3)

\section{KESIMPULAN}

Berdasarkan hasil dan pembahasan di atas, dapat disimpulkan bahwa ada perubahan pengetahuan dan keterampilan peserta dalam hal melakukan percakapan bahasa Inggris sederhana, dan juga kearsipan. Penyampaian materi yang dilakukan oleh fasilitator sudah efektif dan sesuai dengan tujuan yang diharapkan, pelatihan dapat meningkatkan pengetahuan dan keterampilan mereka mengenai Bahasa Inggris untuk Bisnis dan kearsipan, dan materi yang disampaikan oleh fasilitator sudah cukup jelas. Selain itu, fasilitator menguasai dan terampil dalam menyampaikan materi, mendorong peserta untuk terlibat aktif dalam proses pembelajaran, efektif dalam menggunakan media dan metode pembelajaran, mampu membangun komunikasi yang baik antara fasilitator 
dengan peserta, dan dapat mengelola waktu pembelajaran dengan baik. Juga, durasi waktu pelatihan sudah cukup dan asisten mahasiswa bersikap baik terhadap peserta, serta ruang pelatihan sangat layak dan nyaman, alat tulis sangat lengkap, komputer dan sound system dalam kondisi sangat prima. Peserta sangat antusias dan aktif dalam mengikuti kegiatan pembelajaran dan merasa memperoleh banyak manfaat dari keikutsertaanya dalam pelatihan ini. Saran-saran yang bisa diberikan berdasarkan simpulan ini adalah:

- Pelatihan ini terbatas hanya pada pelatihan Bahasa Inggris untuk Bisnis dan Kearsipan. Tentu, pengetahuan dan keterampilan ini kurang memadai untuk mempersiapkan lulusan SMA/K Anak Bina Yayasan Bulir Padi memasuki dunia kerja. Karena itu, perlu pelatihan-pelatihan lainnya seperti komunikasi perkantoran, pembukuan akuntansi sederhana baik menggunakan excel maupun manual, dsb.

- Pelatihan ini hanya menggunakan film video sebagai media pembelajaran English for Business dan hanya membahas sistem pengelolaan arsip secara manual. Pelatihan berikutnya sebaiknya memanfaatkan smartphone sebagai media pembalajaran English for Business dan membahas juga sistem pengelolaan arsip secara digital.

- Dari hasil wawancara terungkap bahwa waktu pelatihan dirasakan kurang oleh peserta. Karena itu, pada berikutnya waktu pelatihan perlu ditambah.
- Untuk mengetahui efektivitas pelatihan, pelatihan hanya ini menggunakan pengukuran kualitatif. Agar lebih obyektif pelatihan berikutnya sebaiknya menggunakan mix methods (gabungan metode kuantitatif dan kualitatif) sebagaimana yang disarankan Creswell (2014).

\section{DAFTAR PUSTAKA}

Ang, R. 2001. Elements of Student Centred Learning. Manila : Office of Research and Publication, Loyola Schools Loyola Antenoe de Manila Uniersity.

Attard, A., Di lorio, E., Geven, K., \&bSanta, R. 2010. Student Centred Learning, Toolkit for students Staffs, and Higher Education Institution. Brussel : Education International and the European Student Union.

Creswell, J.W., 2014. Research Design : Qualitative, Quantitative and Mixed Methods Approaches : fourth edition. Sage publications, Inc.

Febrinastri, F. 2018, November 28. Menaker: Pelatihan Vokasi Punya Kualitas Sendiri. Suara.com. Diakses dari https://www.suara.com/news/20 18/11/28/122825/menakerpelatihan-vokasi-punya-kualitassendiri

Ihsanuddin. 2019, May 16. Jokowi: Kuncinya, Reformasi di Bidang Pendidikan dan Pelatihan Vokasi. Kompas.com. Diakses dari 
Jurnal Widya Laksana, Vol.11, No.1, Januari 2022

https://nasional.kompas.com/rea d/2019/05/16/15034381/jokowikuncinya-reformasi-di-bidangpendidikan-dan-pelatihan-vokasi

Noor, A. F. 2019, November 08. Anggaran Pengembangan Vokasi 2019 Rp 25,9 Triliun. Republika.co.id Diakses dari https://www.republika.co.id/berit a/ekonomi/keuangan/18/11/08/p hvtt2349-anggaranpengembangan-vokasi-2019-rp259-triliun

Rahadian, L. 2019, March 14. INDEF : Kemampuan Angkatan Kerja Tak Sebanding dengan Kebutuhan Industri. Bisnis.com.
Diakses dari https://ekonomi.bisnis.com/read/ 20190314/9/899732/indefkemampuan-angkatan-kerjatak-sebanding-dengankebutuhan-industri

Republik Indonesia. 1992. Peraturan Pemerintah Republik Indonesia Nomor 39 Tahun 1992 Tentang Peranserta Masyarakat Dalam Pendidikan Nasional. Sekretariat Negara. Jakarta Republik Indonesia. 2003. UndangUndang Republik Indonesia Nomor 20 Tahun 2003 Tentang Sistem Pendidikan Nasional. Sekretariat Negara. Jakarta. 